\title{
IMPROVING THE EDUCATION PROCESS BY INTRODUCING INDIVIDUALIZATION AND DIFFERENCE IN PUPILS OF THE 1ST PRIMARY SCHOOL
}

\author{
[ZKVALITNENI EDUKACNIHO PROCESU ZAVEDENIM \\ INDIVIDUALIZACE A DIFERENCIACE U ZAKU 1. ROCNIKU \\ ZAKLADNI SKOLY]
}

\author{
Monika Semradova
}

doi: 10.18355/PG.2022.11.1.11

\begin{abstract}
The article focuses on the current trend of increasing the quality of education, which brings increased demands on the competencies of teachers in the introduction of differentiated teaching in primary school pupils in a heterogeneous complex class, from the very beginning of schooling. In its Strategy for the Educational Policy of the Czech Republic until $2030+$, the Ministry of Education emphasizes didactic procedures in teaching, which will enable differentiation of teaching according to the needs of pupils. However, many teachers are not sufficiently prepared for this and there is very little relevant literature and research to help them in practice. The article summarizes the latest findings in this area, analyzes the concept of internal differentiation, not only its cognitive aspects, but also the social dimension of teaching. It emphasizes the importance of this issue for improving the primary level of primary school in contemporary socio-economic contexts of equal educational opportunities in society. It emphasizes the knowledge of specific students and their individual peculiarities as an important condition for the implementation of internal differentiation. It also discusses the possibilities of differentiation in relation to the content of education, methods and organizational forms of teaching. It brings a list of pedagogical means through which differentiated and individualized teaching is implemented in the teaching process. Improving the level of basic education through internal differentiation of teaching is a long-term and difficult task due to the growing heterogeneity of numerous school groups. The main goal of the research was to map the introduction of differentiated and individualized teaching for five teachers in five primary schools in the Pardubice, Central Bohemia and Hradec Králové regions, focusing on the main subjects of the Czech language and mathematics in 1-3. elementary school class. In our article, we present an analysis of the research survey of the first stage of research, in the first classes of a selected sample of teachers who use differentiated teaching to a greater or lesser extent and the mentioned years will succeed for three years of schooling. In the first stage of the research, we will focus primarily on the use of pedagogical means of differentiation and individualization and their impact on student outcomes and the effectiveness of the teaching process.
\end{abstract}




\section{Key words}

individualization, internal differentiation, external differentiation, pedagogical means, inclusion, didactic procedures and strategies

\section{Anotace}

Článek se zaměřuje na aktuální trend zvyšování kvality vzdělávání, který přináší zvýšené nároky na kompetence učitele při zavádění diferencované výuky u žáků 1 . stupně základní školy v heterogenně složené tř́ídě, a to od samého počátku školní docházky. Ministerstvo školství ve své Strategii vzdělávací politiky České republiky do roku 2030 + zdůrazňuje ve výuce didaktické postupy, které umožní diferencovat výuku dle potřeb žáků. Mnozí učitelé $\mathrm{k}$ tomu nicméně nejsou dostatečně připraveni a relevantní odborné literatury a výzkumných šetření, které by jim v praxi pomohly, je velmi málo. Článek shrnuje nejnovější poznatky z této oblasti, analyzuje pojem vnitřní diferenciace, nejen její kognitivní aspekty, ale i sociální dimenze vyučování. Zdůrazňuje důležitost této problematiky pro zkvalitňování primárního stupně základní školy v soudobých sociálně ekonomických kontextech problematiky rovných vzdělávacích př́ležitostí ve společnosti. Jako důležitou podmínkou pro realizaci vnitřní diferenciace zdůrazňuje znalost konkrétních žáků a jejich individuálních zvláštností. Dále rozebírá možnosti diferenciace ve vztahu $\mathrm{k}$ obsahu vzdělávání, metodám i organizačním formám vyučování. Přináší výčet pedagogických prostředků, prostřednictvím kterých je diferencovaná a individualizovaná výuka implementována ve vyučovacím procesu. Zkvalitňovat úroveň základního vzdělávání cestou vnitřní diferenciace vyučováni je dlouhodobý a vzhledem $\mathrm{k}$ narůstající heterogenitě početných školních kolektivů nelehký úkol. Hlavním cílem výzkumného šetření bylo zmapovat zavádění diferencované a individualizované výuky u pěti učitelů $\mathrm{v}$ pěti základních školách Pardubickém, Středočeském a Královehradeckém kraji se zacílením na hlavní předměty český jazyk a matematiku v 1.-3. tř́iě základní školy. V našem článku podáváme analýzu výzkumného šetření první etapy výzkumu, v prvních trrídách u vybraného vzorku učitelů, kteří ve větší či menši míře používají diferencovanou výuku a uvedené ročníky si povedou po dobu tří let školní docházky. V první etapě výzkumu se zaměříme především na využití pedagogických prostředků diferenciace a individualizace a jejich vliv na výsledky žáků a efektivitu vyučovacího procesu

Výsledky výzkumu mohou dát rovněž důležitou zprávu školsko-politické sfére a školní inspekci o tom, jak učitelé reálně pracují s individuálními zvláštnostmi žáků při diferencované výuce a poskytnout pedagogům cenné informace a doporučení použitelné při vytváření dlouhodobější vize využívání diferencované a individualizované výuky.

\section{Klíčová slova}

individualizace, vnitřní diferenciace, vnější diferenciace, pedagogické prostředky, inkluze, didaktické postupy a strategie 


\section{Úvod}

\section{Diferenciace a individualizace ve školské politice}

Již v Bílé knize byl stanoven požadavek na dodržování humanistických a demokratických hodnot ve vzdělávání prostřednictvím diferenciace a individualizace výuky (MŠMT, 2001 str. 17). Zasedání ministrů školství zemí OECD (Paříž 3. - 4. dubna 2001), reflektující změny sociálního a kulturního kontextu učící se společnosti, přijalo jako společný cíl předpoklad celoživotního učení pro všechny. To předpokládá mimo jiné zvyšovat kvalitu činnosti všech stupňů a druhů škol, především také primárního stupně základní školy. Strategie vzdělávací politiky České republiky v dekádě 20202030 + zdůrazňuje skutečnost, že i přes významný posun spočívající v odstranění řady formálních i neformálních bariér jsou nerovnosti ve vzdělání přetrvávajícím rysem vzdělávací soustavy a současně jedním z jejích dlouhodobých problémů. Dále dochází $\mathrm{k}$ navyšování míry heterogenity žákovských kolektivi̊. Školy stojí před nelehkým úkolem, přijímat všechny děti, bez ohledu na fyzické, intelektuální, sociální, emocionální, jazykové, ekonomické a jiné podmínky a předpoklady. Tato skutečnost klade zvýšené nároky na učitele, pedagogické postupy a kvalitu vyučovacího procesu. Nejdiskutovanějším prvkem vnější diferenciace jsou kontroverzně přijímána víceletá gymnázia. Způsob, jak oslabit důvody $\mathrm{k}$ vnější diferenciaci nabízí posílení diferenciace vnitřní (ability grouping). Důležitost vnitřní diferenciace a individualizace výuky považuje Ministerstvo školství za zásadní a ve svých strategiích cíleně apeluje na zavedení individualizace výuky a didaktických postupů, které umožňují vzdělávání různorodých kolektivů.

\section{Teoretická východiska individualizace a diferenciace - vymezení rámce}

Diferenciací je obecně myšleno rozdělování žáků podle určitých kritérií do různých segmentů vzdělávacího systému (Lucas, 2001). Děje se tak ze snahy vyhovět rozmanitým potřebám různých žáků (Mouralová, 2013). Dalším důležitým pojmem, který je nutné zmínit v této souvislosti je individualizace. Individualizace (individualizovaná výuka) je pozitivní proces ve výuce, je to vlastně způsob vnitřní diferenciace s ohledem na skutečné potřeby dětí a $\mathrm{s}$ ohledem na složení tříd. Pro pedagoga to především znamená vhodný výběr metod práce, společně s propojením vyučovacího stylu se schopnostmi konkrétního žáka. (Kasíková, Straková, 2011). K tomu, aby byla vnitřní diferenciace výukového procesu úspěšná, je zapotřebí další nezbytný soubor jednání pedagoga vzhledem $\mathrm{k}$ žákovi, a to individuální přístup. Ten se projevuje jako respektování specifické vlastnosti jednotlivých žáků, např. individuální styl učení nebo tempo učení. S pojmem individualizace velmi úzce souvisí pojem inkluze. Školy by ve smyslu inkluze měly přijímat všechny děti, bez ohledu na fyzické, intelektuální, sociální, emocionální, jazykové, ekonomické a jiné podmínky a předpoklady. (Lechta 2016). Základní dichotomická linka dělí diferenciaci na vnější a vnitřní, přičemž 
každý typ se dále větví. Diferenciace vnější probíhá jak na úrovni vzdělávacího systému, tak uvnitř školy. Diferenciace školou (tedy typem instituce) znamená rozdělování žáků zpravidla podle kognitivních schopností, studijních předpokladů či studijních výsledků do odlišných trvale oddělených vzdělávacích drah (Greger \& Holubová, 2010, s. 91). Žáci se vzdělávají odděleně ve všech předmětech po celý školní den, přičemž vzdělávání probíhá podle specifických vzdělávacích programů. Anglickým ekvivalentem je tracking či streaming (Gamoran, 1992, s. 11; Hallam, 2012, s. 57; Salchegger, 2016, s. 405). Př́íkladem jsou víceletá gymnázia nebo výběrové školy. Diferenciaci uvnitř školy si lze představit jako rozdělování žáků podle určitých kritérií do výběrových a nevýběrových tříd, popřípadě trvalé rozdělování žáků v určitých předmětech čili tzv. setting (srov. Vališová \& Kasíková et al., 2007, s. 157; Hornby \& Witte, 2014, s. 90). Žáci se mohou také rozdělovat na základě svých zájmů, motivů atp. Příkladem tohoto typu diferenciace mohou být volitelné předměty (srov. Průcha, Walterová, \& Mareš, 2003, s. 45). Vnější diferenciace tak představuje rizikovější formu, jelikož jsou žáci z horní části výkonnostního spektra (high track) vzděláváni izolovaně od žáků ze spodní části výkonnostního spektra (low track), v důsledku čehož dochází $\mathrm{k}$ prohlubování rozdílů ve výsledcích mezi žáky obou drah (Mouralová, 2013, s. 12; Straková, 2010, s. 22. Za méně extrémní formu dělení žáků bývá považována vnitřní diferenciace. Jak již název napovídá, uskutečňuje se na úrovni trrídy či přímo ve třídě. Diferenciace na úrovni tř́ídy probíhá tak, že se žáci rozdělují zpravidla podle kognitivních schopností, studijních výsledků pouze pro určité předměty, zejména pro prredměty hlavní, tedy český jazyk a matematika. $\mathrm{V}$ ostatních předmětech se vzdělávají společně (Greger, 2004, s. 366; Průcha, Walterová, \& Mareš, 2003, s. 44). Kasíková představuje schéma vnitřní diferenciace homogenními skupinami tzv. intra - class - grouping, zde může být dělení kvalitativní i kvantitativní podoby. Schéma popisuje též kombinace využívání skupin ve vybraných předmětech, diferenciaci pracovními družstvy, individualizaci, kombinaci obou schémat. (Kasíková, Valenta, 1994). Tieso popisuje diferenciaci v heterogenní třídě do menších homogenních skupinek, např. dle úrovně čtenářských dovedností (Tieso, 2003, s. 31; Vališová \& Kasíková et al., 2007, s. 157). Anglickým ekvivalentem je within-class (ability) grouping (Hornby \& Witte, 2014, s. 90-91). Hlavní rozdíl mezi vnitřní a vnější diferenciací spočívá $\mathrm{v}$ časovém a organizačním rozložení. $\mathrm{V}$ případě vnější diferenciace dochází $\mathrm{k}$ rozdělení žáků do trvalých vzdělávacích drah, školských institucí či větví, výběrových tříd. Přechod žáků v rámci jednotlivých větví je spíše ojedinělý.

Oproti tomu v prŕípadě vnitřní diferenciace jsou žáci součástí heterogenní třídy a rozdělují se pouze na kratší část školního dne (Greger, 2004, s. 366). $\mathrm{V}$ potaz se přitom nebere, zda se žáci vzdělávají pro určité předměty $\mathrm{v}$ oddělených skupinách či jsou vzděláváni $v$ menších skupinách $v$ jedné tríidě. Důležité je, že vnitřní diferenciace probíhá $\mathrm{v}$ rámci jedné tř́ídy a nabývá podoby flexibilní. Žáci mohou během školního roku přecházet mezi skupinami podle aktuální úrovně jejich schopností - at' už organizačně nebo časově. S vnitřní diferenciací úzce souvisí diferencovaná výuka (differentiated instruction), nicméně významově se oba pojmy liší. Vnitřní 
diferenciace představuje pouze mechanismus, jak rozdělovat žáky $\mathrm{v}$ rámci tř́́dy, již nezaručuje, že bude výuka přizpůsobena individuálním potřebám každého žáka $\mathrm{v}$ dané tř́dě. Jedná se však o mechanismus, který lze použít $\mathrm{k}$ implementaci diferencované výuky (Prast, Weijer-Bergsma, Kroesbergen, \& Luit, 2018, s. 22). Diferencovaná výuka tedy předpokládá změnu charakteru vyučování, kdy je výukový obsah přizpůsoben aktuální úrovni schopností dané skupiny/žáka (Kutnick et al., 2005; Loveless, 1998; Prast et al., 2018; Vališová \& Kasíková et al., 2007; Tieso, 2003). Diferenciace je princip výuky, kdy učitel přizpůsobuje výuku skupinám žáků, nevyžaduje tedy od učitele tvorbu individuálního plánu pro každého žáka (Tucker, 2014). Hlavním cílem učitele je vytvořit dostatečnou různorodost úkolů, které povedou $\mathrm{k}$ jednomu vytyčenému cíli společnému pro všechny žáky (Boaler a další, 2000) a poskytnou jim možnost prezentovat, co se naučili, různými způsoby (Tucker, 2014). Diferenciace výuky na základě zájmů žáka je hlavním faktorem týkajícím se motivace $\mathrm{k}$ učení. Žáci budou $\mathrm{k}$ učení přistupovat více odpovědně a s větším zaujetím, když pro ně bude mít činnost osobní význam a když ji budou vnímat jako smysluplnou Diferenciace procesu vyučování může být vedena formou dělení žáků do skupin na základě jejich úrovně dosahování daného cíle, formou používání úkolů různé obtižnosti, pomocí výukových základen, vrstvení aktivit, komplexní výuky či individualizovaných úkolů a projektů (Anderson, a další, 2010 str. 50).

\section{Heterogenita žákovských kolektivů na základních školách - důvody výzkumu}

Ve školních kolektivech dochází ke zvyšování míry heterogenity žáků Mittler (2000), Lechta (2016), Witburn (2010), Horňáková (2014). Školy mají ve smyslu inkluze přijímat všechny žáky s poruchami učení a chování, žáky nadané, děti ulice, děti z odlehlých oblastí, děti z lingvistických, etnických a kulturních minorit, děti sociálně a emocionálně strádající, ale i děti ze znevýhodněných nebo marginalizovaných oblastí nebo skupin. Zvyšují se tak nároky na kvalitu výchovně vzdělávacího procesu. Dle strategií Ministerstva školství se musí proměnit obsah a způsob vzdělávání tak, aby byl ve školách rozvíjen potenciál všech žáků. Řešením má být selekce odchodu žáků na víceletá gymnázia a posílení vnitřní diferenciace výukového procesu. Zavedení individualizace výuky a didaktických postupů, které umožňují vzdělávání různorodých kolektivů základních škol. Zvyšují se tak především nároky na kvalitu a vzdělání pedagogických pracovníků.

\subsection{Koncepty výzkumu}

Individualizační př́istupy se opírají o široce historicky založenou tradici. Tato tradice vzdělání vychází z pojetí dítěte Dewey, (1932), Komenský (1948). Centrem výuky se stává dítě. Helus (2004, s. 85), chápe osobnost jako psychologický celek, který je složený z individuálních částí, a ty jsou vzájemně propojené. Dle Heluse je nutné pracovat nejen s tím, co se má žák naučit, ale také s tím, jaké má žák dispozice (postojové, informační, názorové). Důležitý je vztah mezi učitelem a žákem. V našem výzkumu jsme 
se zaměřili především na využití pedagogických prostředků vnitřní diferenciace ve výuce učitelem, ale také ne žáky a jejich aktivitu a motivovanost ve spojení s diferencovanou výukou a individuálním přístupem k žákům. Zkoumali jsme učitelovu osobnost, jako tvůrce a manažera obsahu výuky, nebot' hraje významnou roli pro rozvoj žákovy individuality a zaměříme se též na vztah mezi učitelem a žákem, a to na pedagogicko psychologickou diagnostiku a na sociopsychické dispozice, které jsou utvářeny ve školním prostředí. (Hrabal, 1989). Předmětem našeho zájmu bude též zkoumání metod a postupů, dělení dle Dittricha (1992), které jsou využívány pro zjištění diagnostiky žáků. Podstatný pro náš výzkum bude též důvod, proč byl žák zařazen do určité skupiny v rámci diferencované výuky. Zaměřili jsme se na diferenciaci obsahu vyučování. Dle Dittona (2002, s. 199-200), je kvalita výuky záležitostí reflexe, jež se v závislosti na konkrétní didaktické koncepci zaměřuje na cílovou, obsahovou metodickou (strukturní) a vztahovou dimenzi výuky. Obsahově zaměřený př́stup spadá do okruhu úvah o kultuře vyučování a učení. Weinert (1997). Provázanost obsahu s činností, vystižená konstruktem intencionalita, podmiňuje hodnocení kvality výuky. Intencionálně chápaná kvalita výuky závisí na tom, $\mathrm{v}$ jaké míře je způsobem žákovy činnosti a komunikace podporováno zvládání a učení se obsahu. Tím se zároveň rozvíjejí žákovy cílové dovednosti a kompetence $\mathrm{s}$ obsahem zacházet. (Amade-Escot, 2005, s. 131). Kvalita výuky logicky předpokládá rozlišení nižší a vyšší kvality. Toto rozlišení závisí na reálném průběhu výuky, tj. na jejich faktech (Slavík, Janík, 2005). Diferencovanou a individualizovanou výuku jsme detailně sledovali na úrovni každodenní práce učitele. V tomto smyslu jsme proces sledovali na základě biografické zkušenosti učitele. Na této úrovni lze proces diferenciace a individualizace výuky rozčlenit do tří fází 1 . Rozhodnutí o použití, 2. Reálné použití, 3 . Reflexe hodnocení efektů. Naším cílem bylo popsat všechny tyto fáze ve vzájemných souvislostech a popsat tak každodenní využití diferenciace do hloubky. V našem pojetí jde o proces cyklický, nebot' skutečnost, jak učitel ve svém prístupu vyhodnotí efekty použití diferenciace a individualizace ve výuce předznamenává, zda je použije znovu a jakým způsobem. V našem článku podáváme analýzu výzkumného šetření první etapy výzkumu prováděného $\mathrm{v}$ prvních ročnících základní školy u pěti vybraných učitelů. Kteří ve větší či menší míŕe používají diferencovanou výuku.

\subsection{Metodologické postupy a design výzkumu}

Jako výzkumný design jsme použili vícepř́ípadovou studii. Pro zkoumání konkrétních jevů jsme zvolili kvalitativní výzkum, nebot' je vhodným prostředkem zejména proto, že umožňuje interpretovat a popsat situaci na základě vyjádření dojmů, pocitů a zkušeností učitelů a žáků. Švaříček (2007). Tvorba dat $\mathrm{k}$ získání požadovaných výsledků proběhla formou polostrukturovaných rozhovorů. Byl kladen důraz na důkladný a bohatý popis respondentovy zkušenosti. Co se týká rozhovorů, ty byly vždy vytvářeny postupně. Rozhovor byl vždy zrealizován, přepsán a analyzován a kódován dř́ive, než proběhl rozhovor následující. Byl tak poskytnut prostor pro revizi plánu a strategie vedení rozhovoru (Koutná Kostíková, Čermák in: 
Řiháček a kol., 2013, s. 15). Proces analýzy jsme začali u prvního př́ípadu a provedli ho u každého př́ípadu samostatně, a to včetně identifikace témat. Byl tak zachován individuální přístup ke každému jednotlivému př́padu. Po detailním prostudování analýz polostrukturovaných hloubkových rozhovorů jsme zařadili zúčastněné pozorování prováděné formou dlouhodobého, systematického a reflexního sledování způsobů a postupů implementace diferenciace a individualizace do vyučovacího procesu Švaříček (2007). Hlavním cílem pozorování bylo analyzovat edukační význam, který diferencované vyučování přináší a triangulovat verbální vyjádření učitelů a žáků z rozhovorů. Bassey (2006, s. 81). Byla provedena hloubková analýza pedagogických prostředků diferencované a individualizované výuky ve zkoumaných ročnících základní školy. Výzkumné šetření bude probíhat po dobu tř́ let. Zaměříme se proto ve svém výzkumu podrobně na vnitřní diferenciaci výuky 1 . - 3. trríd základní školy se zacílením na předměty český jazyk a matematika.

$\mathrm{V}$ našem článku podáváme analýzu výzkumného šetření první etapy výzkumu, v prvních ročnících u vybraného vzorku učitelů, kteří ve větši či menší míře používají diferencovanou výuku a uvedené ročníky si povedou po dobu tří let školní docházky. V první etapě výzkumu se zaměříme především na využití pedagogických prostředků diferenciace a individualizace v první trrídě základní školy a jejich vliv na výsledky žáků a efektivitu vyučovacího procesu.

\subsection{Výzkumný vzorek základních škol}

Pro svi̊j výzkum jsem zvolila pět různých učitelů prvních ročníků různého věku a různé délky praxe, $\mathrm{z}$ pěti tříd různých škol, které obsahovaly celkem 130 žáků z Pardubického, Hradeckého a Středočeského kraje. Ve svém zkoumání jsme se zaměřili na diferenciaci obsahu vyučování, vyučovacího procesu a způsobu prezentování činnosti žáka a na diferenciaci prostředí, ve kterém výuka probíhá. První učitelkou je velmi zkušená paní učitelka, která vyučuje již 32 let. Je vedoucí metodického kabinetu a má na starosti vedení začínajících pedagogů, zabývá se lektorskou činností a ve své výuce používá prvky diferenciace a individualizace. Specializuje se též na mezinárodně uznávanou metodu Fie. Vyučuje ve velké pardubické škole s kapacitou 800 žáků. Jedním z hlavních cílů školního vzdělávacího programu školy je dát šanci $\mathrm{k}$ co nejlepšímu vzdělání všem žákủm, žákům nadaným, mimořádně nadaným i žákủm se speciálními vzdělávacími potřebami. Druhá paní učitelka vyučuje 15 let v menší škole v Pardubickém kraji. Specializuje se na čtenářskou gramotnost. Ve své výuce upřednostňuje hromadnou výuku a individuální př́ístup. Vyučuje ve venkovské škole, blízko, Pardubic, která má kapacitu 125 žáků. Je to úplná škola, která staví své zaměření na kombinaci plánování a spoluzodpovědnosti za zvládnutí učiva a na projektovém vyučování, kritickém myšlení, učení v souvislostech, prezentace výstupů žáků. Třetí paní učitelka je mladou paní učitelkou, která má dva roky praxe, pro svou práci je velmi aktivní, využívá ve své výuce prvky diferenciace a individualizace, skupinovou práci a další aktivizační metody a formy výuky. Vyučuje na velké škole v Hradci Králové, která má kapacitu 970 žákủ, kteří 
jsou různorodým vzorkem co do znalostí, chování, zájmů. Škola se zaměřuje na žáky, kteří potřebují více času na osvojení učiva, vychází ze specifických potřeb žáků. Čtvrtou učitelkou je velmi zkušená paní učitelka, která vyučuje již 34 let. Ve své práci využívá spiše klasické metody, k žákủm přistupuje individuálně. $\mathrm{V}$ rámci srovnávacích testů, dosahuje její tř́ída vždy výborných výsledků. Vyučuje v plně organizované škole maloměstské škole $\mathrm{s} 1$. až 9. ročníkem, která vyučuje dle školního vzdělávacího programu Škola-základ života. Pátou učitelkou, je paní učitelka, která vyučuje 10 let na venkovské škole ve Středočeském kraji. Svou práci dělá s velkým zaujetím. Používá spíše klasické vyučovací metody, specializuje se na čtenářskou gramotnost a na sestavení schémat skupin dle zájmu žáků. Vyučuje na menší venkovské základní škole bez specifického zaměření, která má kapacitu 460 žáků. Škola se zaměřuje na žáky, kteří potřebují více času na osvojení učiva, vychází ze specifických potřeb žáků.

Pro výzkum jsem vybrala záměrně školy, ve kterých se objevuje zvýšená heterogenita žáků z lingvistických, etnických a kulturních minorit, děti sociálně strádající, děti s poruchami učení a chování, ale i žáci nadaní. Výzkumný vzorek představoval 130 žáků z pěti trríd základní školy.

\section{Analýza využití pedagogických prostředků vnitřní diferenciace}

Předmětem našeho zkoumání bylo především využití pedagogických prostředků vnitřní diferenciace a individualizace ve vyučovacím procesu na prvním stupni základní školy. Předmětem zkoumání byl rozvoj potenciálu každého žáka a jeho individuální zvláštnosti při využití diferencované a individualizované výuky a zefektivnění kvality vyučovacího procesu.

Výzkumné šetření první etapy výzkumu probíhalo $\mathrm{v}$ prvních ročnících u vybraného vzorku učitelů, kteří ve větší či menši miřre používají diferencovanou výuku. Zaměřili jsme se především na složení třídních kolektivů žáků a jejich heterogenitu. Sledovali jsme pedagogickou diagnostiku učitele a využití metod pedagogické diagnostiky. Využití diferenciace jako podpůrných opatření u žákủ ze SVP. Zaměřili jsme se na skutečnost, jaké důvody vedou učitele $\mathrm{k}$ diferencované výuce. Velmi podrobně jsme se zaměřili na využití pedagogických prostředkủ diferenciace ve vyučovacím procesu, tedy na využití diferenciace rozsahu učiva, na stanovení základní míry učiva a vytvoření učiva rozšiřujícího vzhledem $\mathrm{k}$ individuálním zvláštnostem žáků, zadávání diferencovaných úloh pro žáky různého kognitivního a učebního stylu. Zajímalo nás, zda učitelé využívají zadávání diferencovaných úloh žákủm na základě typologie osobnosti MBTI Miková, Š., \& Stang, J. (2015)., dle pedagogické diagnostiky učitele stanovené na základě pozorování žáka. Dalším záměrem bylo sledování diferenciace rozsahu práce, tedy stanovení minima učiva, zvládnutelného všemi žáky a zvyšování míry rozsahu učiva vzhledem $\mathrm{k}$ individuálním zvláštnostem žáků. Dále pak sledování diferenciace časového hlediska při řešení úloh vzhledem $\mathrm{k}$ individuálním zvláštnostem žáků. Zkoumali jsme využití diferenciace obtížnosti zadávaných úkolů, gradovaných a bonusových úloh v edukačním procesu. Zadávání úloh při využití Bloomovy taxonomie vzdělávacích cílů s využitím úrovní myšlení higher order thinking, lower 
order thinking. Dále pak snížení obtížnosti učiva pro žáky LMP. Zadávání individuálních úkolů různé obtižnosti. Diferenciaci pracovních materiálů, jako napřr. pracovních listů, diktátů, testů.

Důležitá pro nás byla též analýza zadávaných diferencovaných úloh a její vliv na zlepšení kvality vyučovacího procesu. Sledování a analýza efektivity a míry využití diferencovaných úloh při hromadné a skupinové výuce při využití různých strategií a schémat skupinové práce. Zajímalo nás, zdali má využití pedagogických prostředků vliv na efektivitu vyučovacího procesu, zejména na zlepšení zájmu a motivace žáků o učení, na zlepšení výsledků žáků a $\mathrm{v}$ neposlední řadě na zlepšení socializace a sociální interakce mezi žáky. Konkrétně jsme se zaměřili na analýzu níže uvedených pedagogických prostředků. Zejména na sledování a analýzu zlepšení zájmu a motivace o výuku při zadávání diferencovaných úloh. Pedagogický prostředek diferenciace $\mathrm{v}$ rámci skupinové práce při práci $\mathrm{s}$ homogenními či heterogenními skupinami. Zaměřili jsme se na stabilitu a homogenitu sestavených schémat skupin, dále pak na výzkumnou analýzu kritérií vytváření homogenních skupin. Zajímalo nás hodnocení a výzkumné posouzení práce $\mathrm{v}$ homogenních skupinách. Zaměřili jsme se též na analýzu schémat heterogenních skupin, na výzkumné sledování a analýzu skupinové práce, strategií a schémat skupinové práce a na hodnocení a výzkumné posouzení práce $\mathrm{v}$ heterogenních skupinách. Zajímalo nás, zda dochází ke zlepšení motivace žáků $\mathrm{k}$ učení a ke zlepšení sociální interakce mezi žáky při užití skupinové práce. 
Tabulka 1 Pedagogické prostředky diferencované a individualizované výuky na ZŠ

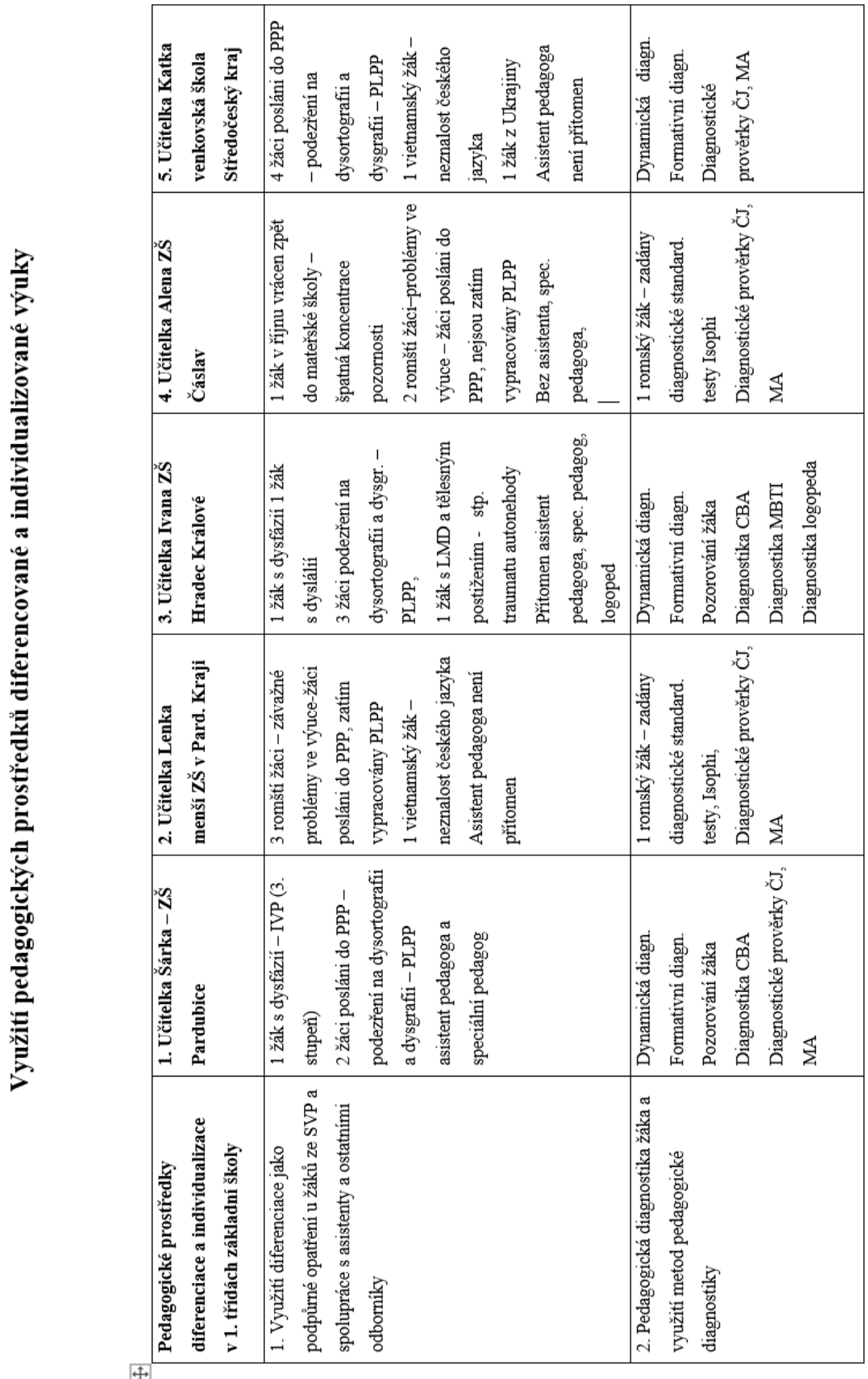




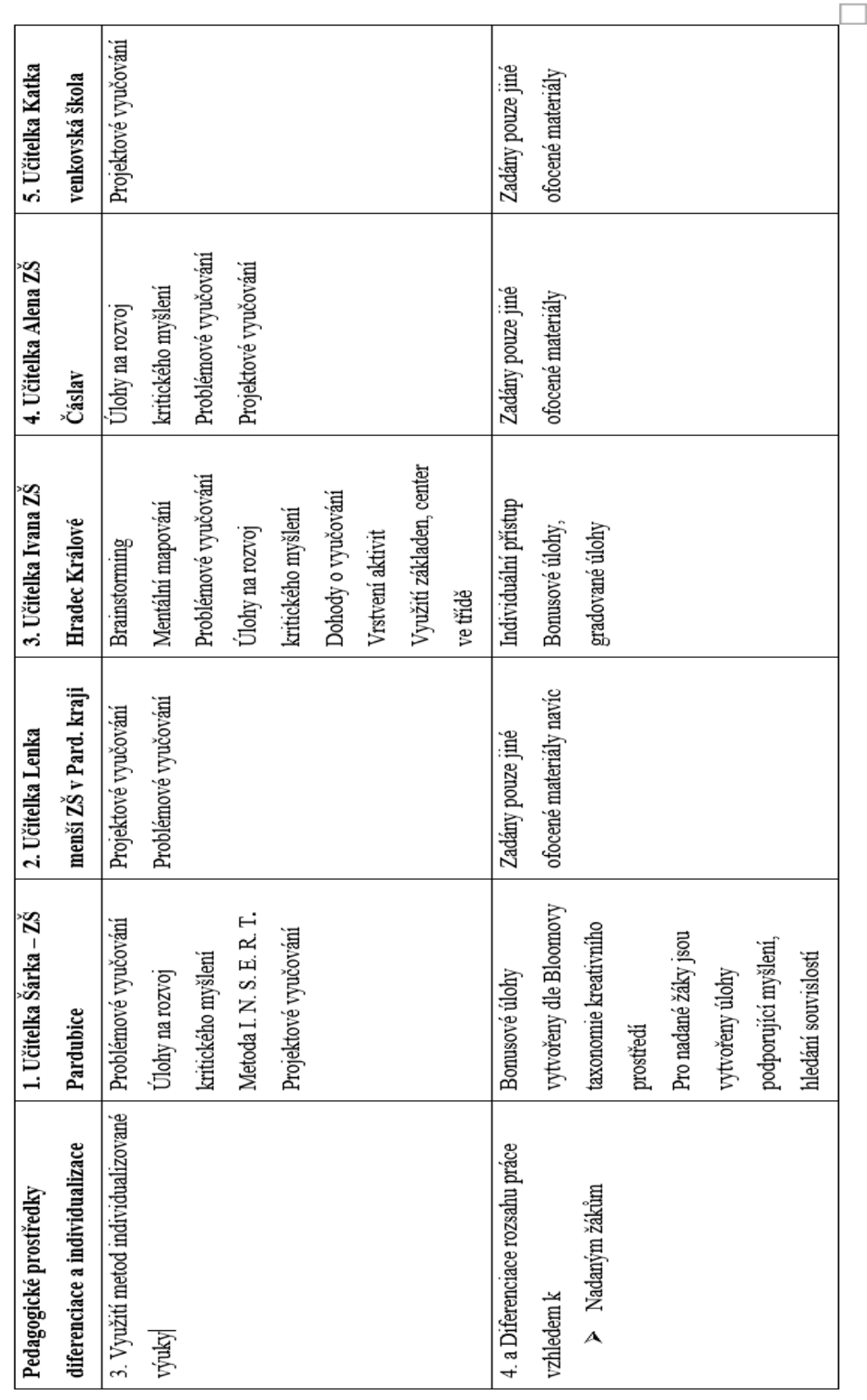




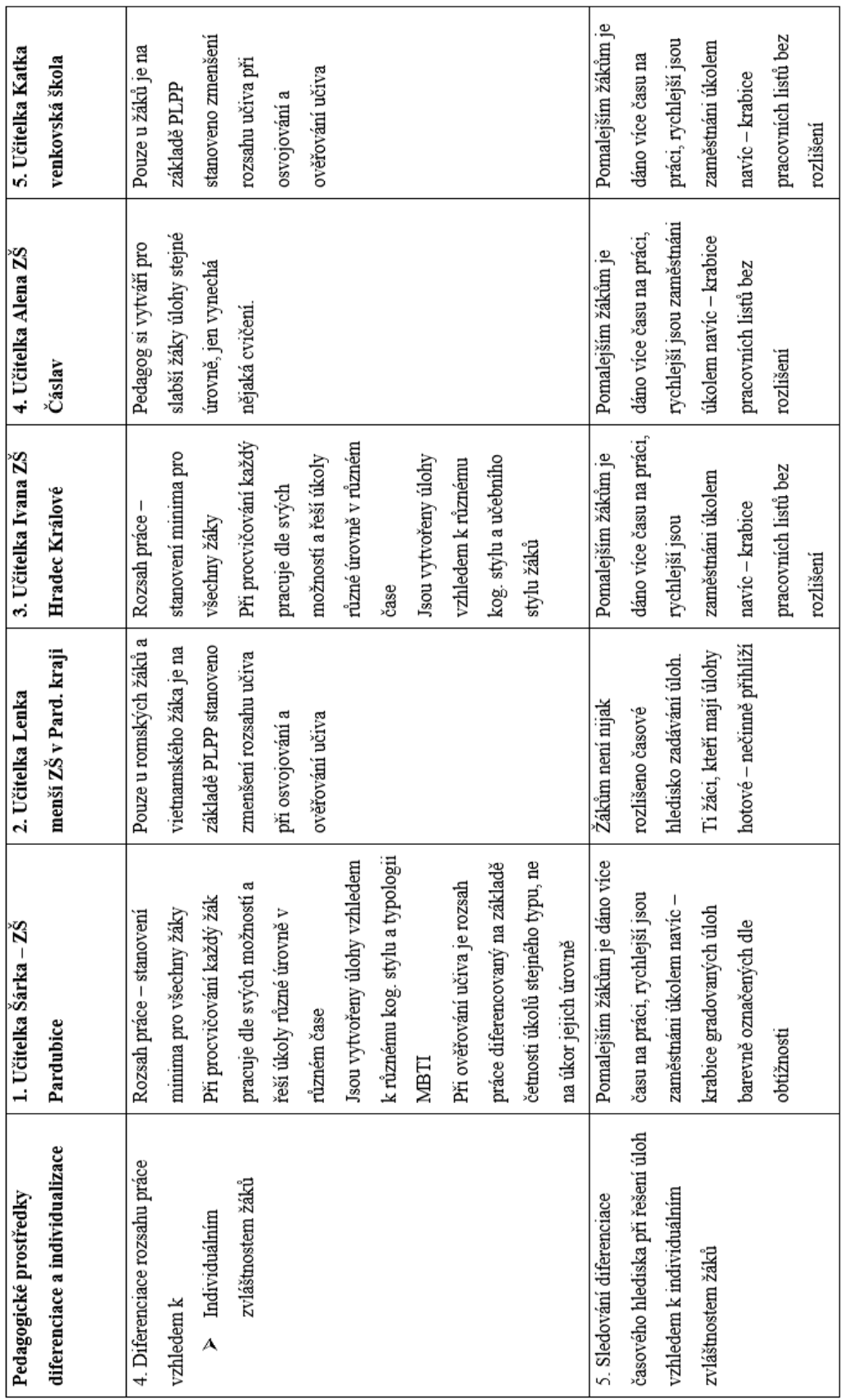




\begin{tabular}{|c|c|}
\hline 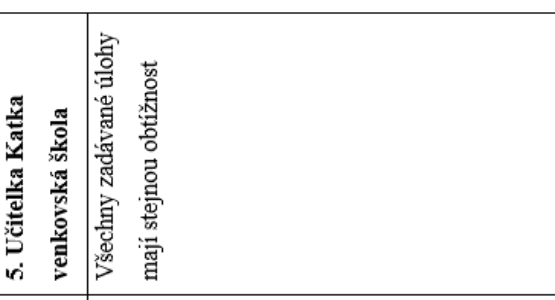 & 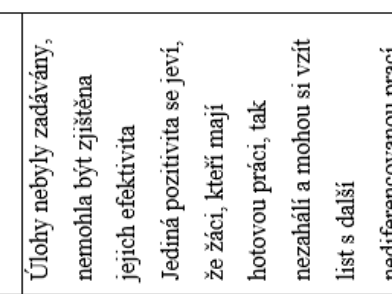 \\
\hline 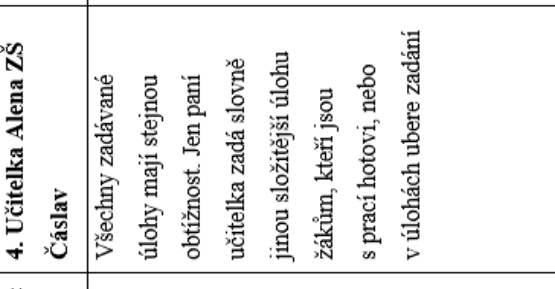 & 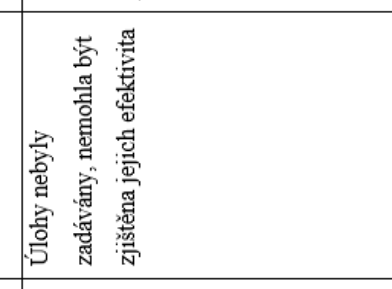 \\
\hline 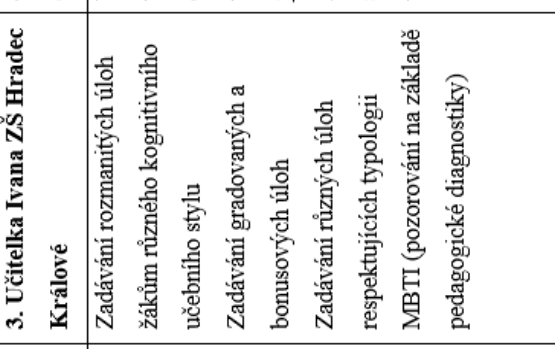 & 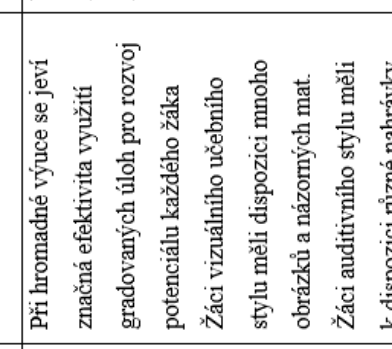 \\
\hline 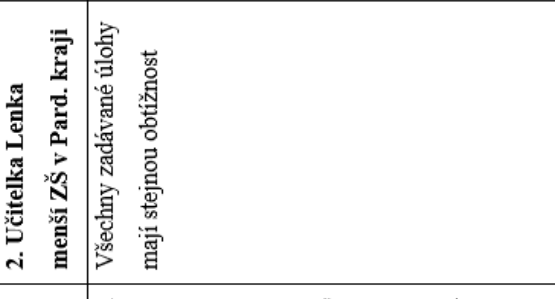 & 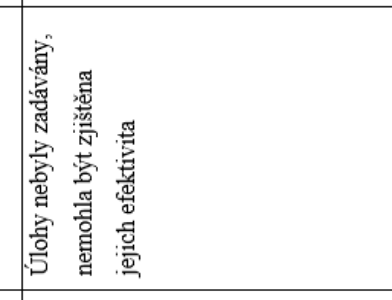 \\
\hline 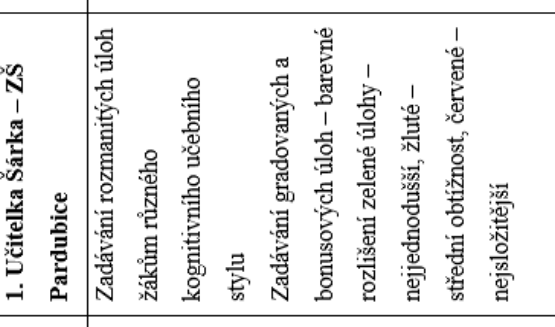 & 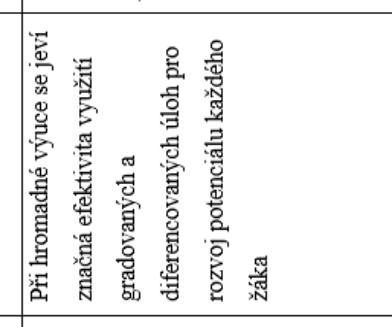 \\
\hline 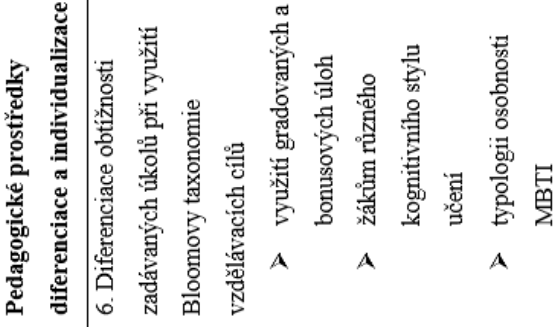 & 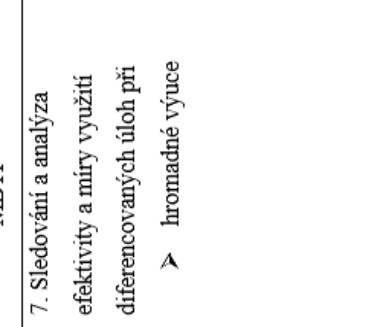 \\
\hline
\end{tabular}




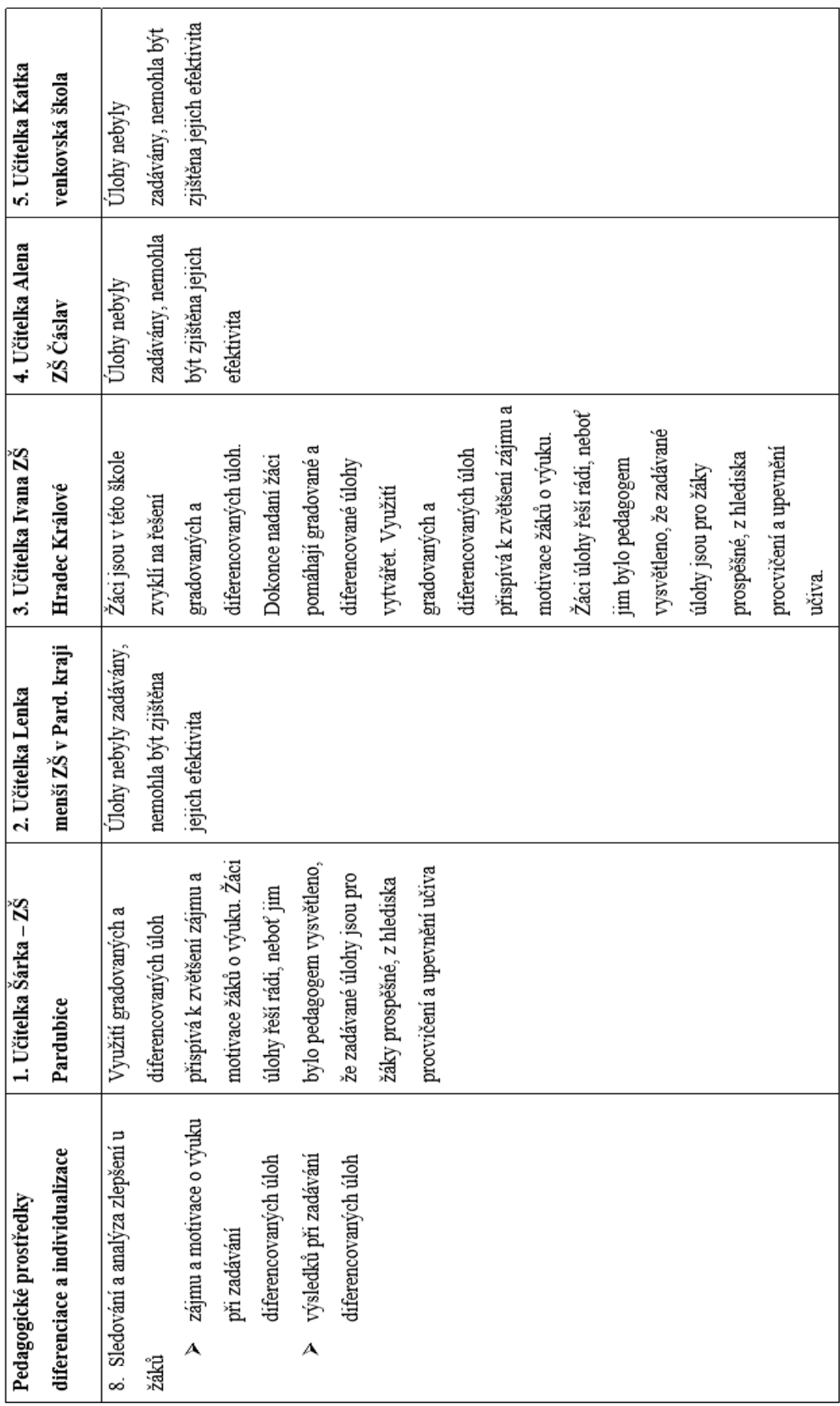




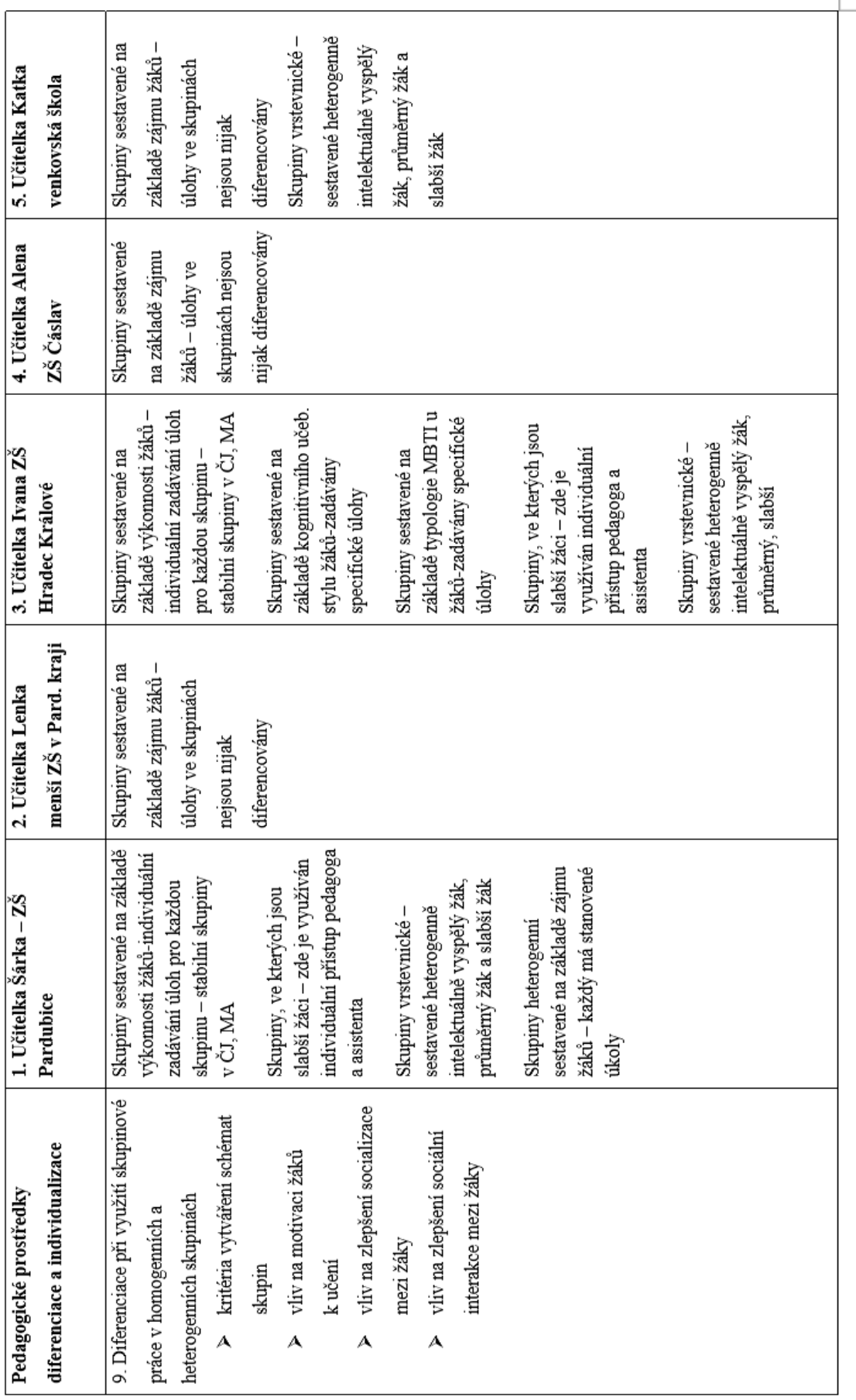




\section{Výsledky první fáze výzkumu - školní rok 2021/ 2022}

První výzkumná etapa probíhala $\mathrm{v}$ prvních ročnících u vybraných pěti pedagogů, kteří používají ve větší či menší míře diferencovanou a individualizovanou výuku. Pro náš výzkum jsme vybrali záměrně pedagogy různého věku, zaměření a různé délky praxe, $\mathrm{z}$ pěti prvních tř́íd, které obsahují celkem 130 žáků z Pardubického, Královehradeckého a Středočeského kraje. V první etapě výzkumu jsme se zaměřili detailně na analýzu využití pedagogických prostředků diferenciace a individualizace. Využití míry pedagogických prostředků jsme vyhodnotili procentuálním vyjádřením, přehledně zpracovali do tabulek a znázornili do sloupcového grafu. Jako výzkumné kvalitativní metody jsme použili hloubkové pozorování a hospitační videostudii, polostrukturované rozhovory s učiteli a se žáky.

Výzkum dokázal, že heterogenita žákovských kolektivů stále narůstá. První tř́ídy obsahují žáky $\mathrm{s}$ poruchami učení, chování, žáky s fyzickými, intelektuálními, sociálními, individuálními zvláštnostmi, ale i žáky rozmanitých národností, žáky emocionálně strádající a žáky nadané. Z našeho výzkumu vyplývá, že jou školy na tuto skutečnost ve větši či menší míre připraveny. Využití diferenciace jako podpůrné opatření u žáků ze SVP využivá 86 \% zkoumaných škol. K úpravě učiva vzhledem $\mathrm{k}$ individuálním zvláštnostem a specifickým poruchám žáků jsou vypracovány plány pedagogické podpory. Nejefektivněji jsou využívány v sídlištních školách $\mathrm{s}$ větší kapacitou žákủ v Pardubicích a v Hradci Králové, které spolupracují s odborníky, logopedy a speciálními pedagogy. Tito odborníci pracují s problémovými žáky $\mathrm{v}$ rámci vyučování a sestavují s pedagogy plán pedagogické podpory. Pomáhají též při zpracování pedagogické diagnostiky žáka. Pedagogové se shodli na skutečnosti, že je nedílnou součást výchovně vzdělávacího procesu plánování výuky a efektivní nastavení podpůrných opatření pro žáky se SVP. Ředitelé škol ocenili přítomnost školního psychologa, speciálního pedagoga a logopeda za velmi efektivní prínos pro diagnostiku individuálních zvláštností žáků, poruch učení, chování a jiných individuálních zvláštností žákủ. Základní škola v Hradci Králové se ve svém ŠVP zaměřuje na žáky se specifickými a individuálními zvláštnostmi. Cílem je určit aktuální stav „,učení“ u žáka a navrhnout pedagogická opatření. Ve tř́idě je využívána diagnostika dynamická, formativní, diagnostika MBTI, CBA. Naopak se v menší škole na Pardubicku vyskytla absence odborníkủ i asistentů pedagoga. Selhávaly též pedagogovy př́stupy diferenciace a individualizace u žáků s PLPP, byly využívány pouze diagnostické prověrky $\mathrm{z}$ českého jazyka a matematiky. Podobné výsledky byly prokázány i v základní škole v Čáslavi, kde byla abstinence asistenta pedagoga. Ve škole působil externě speciální pedagog, který u žáků zařadil diagnostické testy Isophi pro žáky 5.-7. let, což je pedagogická diagnostika je nástroj určený pro práci učitele s dítětem. Je zaměřen na zjištování úrovně dovedností dítěte $\mathrm{v}$ sedmi základních oblastech. Jedná se o grafomotoriku, matematické představy, prostorovou orientaci, časovou orientaci, zrakové vnímání, sluchové vnímání a řeč a verbální myšlení. Pedagogická diagnostika je využívána v 79 \% zkoumaných škol. 
Metody individualizované výuky byly využívány ve větší či menší míře v 50 \% zkoumaných škol. Největší procentuální zastoupení implementace metod diferencované a individualizované výuky se prokázalo ve škole v Hradci Králové, která pracuje dle vzdělávacího programu Škola pro život. Škola se zaměřuje především na žáky, kteří potřebují více času na osvojení učiva a vychází ze specifických potřeb žáků. První tř́ídu vyučuje mladá paní učitelka, která využívá širokou škálu metod diferencované a individualizované výuky např. úlohy na rozvoj kritického myšlení, mentální mapování, problémové vyučování, úlohy na rozvoj kritického myšlení, uzavírá $\mathrm{s}$ žáky dohody o vyučování, používá vrstvení aktivit a využívá základny a výuková centra ve tř́ídě, Tomlinson (2017). Druhou školou, která využívá hojné zastoupení metod diferencované a individualizované výuky, je sídlištní škola v Pardubicích, ve škole vyučuje paní učitelka středního věku, která se zaměřuje na skupinovou práci, metodu Fie a využívá metody jako problémové vyučování, úlohy na rozvoj kritického myšlení, projektové vyučování a metodu I. N. S. E. R. T. V čáslavské škole a v menší škole na Pardubicku jsou metody diferencované a individualizované výuky zastoupeny pouze $\mathrm{v}$ rámci projektového a problémového vyučování. Výuka je v těchto školách vedena spíše klasickým způsobem.

$\mathrm{V}$ závěrečné analýze první etapy výzkumu jsme se podrobně zaměřili především na využití pedagogických prostředků diferenciace rozsahu, diferenciaci časového hlediska a diferenciaci obtížnosti zadávaných úloh práce vzhledem $\mathrm{k}$ individuálním zvláštnostem žáků. Předmětem našeho zájmu bylo sledování a analýza efektivity využití diferencovaných úloh při

170 hromadné či skupinové výuce a na motivaci žákủ $\mathrm{k}$ učivu a jejich školní výsledky. Pedagogické prostředky diferenciace rozsahu zadávaných úloh byly využity pouze v $64 \%$ sledovaných škol. Největší míru zastoupení diferenciace zadávaných úloh vykazovala základní škola v Hradci Králové. Mladá paní učitelka s dvouletou praxí měla stanovené minimum učiva pro všechny žáky, rozsah práce přizpůsobovala vzhledem $\mathrm{k}$ individuálním zvláštnostem žáků. Při procvičování každý žák pracoval dle svých možností a řešil úkoly různé úrovně $\mathrm{v}$ různém čase. Paní učitelka spolupracovala $\mathrm{s}$ psychologem a speciálním pedagogem, na základě této spolupráce a pedagogické diagnostiky znala velmi dobře všechny své žáky, což dle jejich slov bylo základním předpokladem pro kvalitu a efektivitu vyučovacího procesu. Vytváŕela tak pro žáky úlohy vzhledem ke kognitivnímu stylu a typologii MBTI, úlohy byly zaměřené na rozvoj kritického myšlení a využívaly Bloomovu taxonomii kreativního myšlení žáků v souvislostech při využití úrovní myšlení higer order thinking. Speciální pozornost byla věnována též žákům nadaným. Při ověřování učiva byl rozsah práce diferencovaný na základě četnosti úkolů stejného typu, ne na úkor jejich úrovně. Byly zadávány diferencované diktáty i diferencované písemné práce s bonusovými úlohami. Co se týče časového hlediska, pomalejším žákům bylo dáno více času na práci, rychlejší mohli zvolit práci s úkolem navíc. Pro vyučovací jednotku si paní učitelka vytvářela vždy tři úrovně př́prav pro různé spektrum individuálních zvláštností žáků.

Diferenciace obtížnosti zadávaných úloh byla využívána ve $43 \%$ zkoumaných škol. Z hlediska diferenciace obtižnosti zadávaných 
diferencovaných úloh byly zadávány rozmanité úlohy žákům různého kognitivního učebního stylu a gradované úlohy vytvořené dle obtížnosti. Ve spolupráci se školním psychologem byly vytvářeny různé úlohy respektující typologii MBTI. Základní škola v Pardubicích pracovala s diferenciací zadávání úloh velmi podobným způsobem. Gradované úlohy měli žáci barevně odlišeny $\mathrm{v}$ boxech, které měli umístěny na koberci a kdykoli při práci mohli zásobárnu úloh při vyučování využít. Ve dvou výše uvedených školách měla práce s diferencovanými úlohami pozitivní vliv na výuku žáků. Při hromadné výuce se projevila značná efektivita využití gradovaných a diferencovaných úloh pro rozvoj potenciálu každého žáka Dle rozhovorů s pedagogy a pozorování vyučovacího procesu bylo zjištěno, že využití gradovaných a diferencovaných úloh přispívá $\mathrm{k}$ zvětšení zájmu a motivace žáků o výuku. Žáci úlohy řešili se zájmem, nebot’ jim bylo pedagogem vysvětleno, že zadávané úlohy jsou pro žáky prospěšné, z hlediska procvičení a upevnění učiva Žáci též hodnotili diferencovanou práci s úlohami velmi pozitivně. Jejich řešení provázel zájem a motivace dozvědět se více a látku si více zopakovat. Zadávání úloh pro ně bylo samožrejmostí. Po skončení práce ve skupinách bylo využito sebehodnocení a formativní hodnocení, které poskytlo pedagogovi efektivní zpětnou vazbu provedené práce. Velmi pozitivní bylo též zjištění, že nadaní žáci se podíleli na vytváření diferencovaných úloh. Při srovnávacích diagnostických prověrkách $\mathrm{v}$ předmětech českém jazyce a matematice třídy, které pracovali diferencovaně se zadávanými úlohami měly lepší výsledky než třídy, které pracovali klasickým způsobem bez diferenciace učebního materiálu. Na základní škole $\mathrm{v}$ Č́slavi byla práce $\mathrm{s}$ diferenciací úloh využita $\mathrm{v}$ menší míre. $\mathrm{V}$ rámci diferenciace rozsahu práce byly zadány pouze jiné ofocené materiály, $\mathrm{z}$ hlediska rozsahu práce si pedagog vytvářel pro slabší žáky jednodušší úlohy. Při sledování diferenciace časového hlediska bylo pomalejším žákủm dáno více času na práci, rychlejší žáci byli zaměstnáni úkolem navíc. Co se týče obtížnosti zadávaného úkolu, všechny zadávané úlohy měly stejnou obtížnost. Jen paní učitelka zadala slovně jinou složitější úlohu žákům, kteř́i byli s prací hotovi, formou doplňující otázky k úloze. Na venkovské základní ve Středočeském kraji škole nejvíce abstinovala diferenciace práce se zadávanými úlohami, a to při využití rozsahu práce a obtížnosti zadávaných úkolů. Při diferenciaci práce s časem si žáci, kteří byli s prací hotovi, mohli vzít jiný ofocený list a vypracovat ho. Efektivita práce $\mathrm{s}$ diferencovanými úlohami v čáslavské a venkovské škole tak nemohla být zjištěna. Nevýhodou absence práce s diferencovanými úlohami byla skutečnost, že nadaní žáci se nemohli uplatnit a slabší žáci naopak selhávali při řešení úloh a cítili se pak negativně před ostatními žáky, kterým řešení úloh problém nečinilo. Do této tř́idy by bylo vhodné zavést diferencované úlohy pro žáky. Míra efektivity diferencovaných úloh na motivaci žáků pro výuku a školní výsledky byla zjištěna u 44 \% zkoumaných škol. V posledních dvou zmiňovaných školách jsme doporučili pedagogům školení zaměřená na diferencovanou a individualizovanou výuku na prvním stupni základní školy. Využití diferencovaných úloh při hromadné výuce byla pak zjištěna pouze u $40 \%$ zkoumaných škol. 
Poslednímu pedagogickému prostředku diferenciace a individualizace, kterému se budeme věnovat, je diferenciace při využití skupinové práce $\mathrm{v}$ homogenních a heterogenních skupinách. Zaměřili jsme se na kritéria vytváření schémat skupin, na vliv a na motivaci žáků k učení, dále pak na zlepšení socializace a sociální interakce mezi žáky. Skupinová práce diferencovaného zaměření vzhledem $\mathrm{k}$ individuálním zvláštnostem žáků bylo využíváno v 53 \% výzkumného vzorku základních škol. V plné míře využívaly diferencovanou skupinovou výuku a schémata skupin základní škola v Hradci Králové a základní škola v Pardubicích. Zpočátku, v měsících záríi, rríjnu a listopadu používali třídy schémata skupin heterogenních vytvořených na základě zájmu žáků. Důvodem bylo ponechání času na poznání žáků a vytvoření pedagogické diagnostiky. Základní škola v Hradci Králové s kreativní paní učitelkou používala skupiny sestavené na základě výkonnosti žáků. Vznikaly tak v měsíci prosinci stabilní skupiny v českém jazyce a matematice. Pro každou skupinu byly vytvářeny úlohy různé obtížnosti od nejjednodušších až po ty nejsložitější. Žáci ve skupině měli přesně rozděleny role tak, aby byli všichni žáci pracovně vytíženi a práce probíhala efektivním způsobem. Po vytvoření pedagogické diagnostiky byly sestaveny skupiny na základě různého kognitivního učebního stylu u žáků. Pro tyto skupiny byly upraveny základní úlohy a vytvořeny specifické úlohy pro každý učební styl. Mohli se tak plně uplatnit žáci vizuálního typu, kteří měli k dispozici, grafy, mapy, názorné obrázky pro řešení úloh. Žáci auditivního stylu měli k dispozici nahrávky, zvukové materiály, mohli využít hraní rolí a zapojit se do vzájemné diskuse. Skupiny sestavené na základě kinestetického stylu se věnovaly vystřihování informací. Žáci si psali poznámky, manipulovali s rozstř́ihaným materiálem a sestavovali řešení. Paní učitelka ve spolupráci $\mathrm{s}$ odborníky školy-psychologem a speciálním pedagogem se zaměřili též na typologii MBTI u žáků a sestavili společně úkoly pro specifické skupiny žáků. Tato oblast je velice zajímavá a podrobně ji budeme sledovat $\mathrm{v}$ dalších dvou letech výzkumu. Hojně používané byly $\mathrm{i}$ skupiny vrstevnické, které obsahovaly tři žáky, žáka intelektuálně zdatného, žáka, průměrného a žáka slabšího. Paní učitelka na základní škole v Pardubicích používala stejná schémata skupin, kromě skupin sestavených na základě typologie MBTI. Věnovala se však navíc využíí metody Feuersteina, zkráceně Fie. Paní učitelka měla speciálně sestavené pracovní listy, které rozvíjely kognitivní funkce a kritické myšlení. $\mathrm{Na}$ základě obtížnosti pracovních listů sestavovala skupiny dle intelektu. Dle slov paní učitelky metoda rozvíjí vnitřní motivaci a pozornost žáků, vyjadřování a porozumění, dovednost pracovat $\mathrm{s}$ chybou, efektivně a strategicky řešit problém a v neposlední řadě rozvíjet emoční inteligenci.

Ve škole v Pardubicích je též hojně využívána práce ve dvojicích slabší a intelektuálně zdatnější žák při využití podnětného matematického prostředí při řešení úloh matematiky pana profesora Hejného. Podnětné výukové prostředí je flexibilní, lze jej přizpůsobit aktuálním podmínkám v každé třídě a je bohatým zdrojem matematických úloh (Roubíček et al., 2010). Důraz zde byl kladen na vzájemnou spolupráci a sociální interakci žáků. Na základě analytického pozorování vyučovacích hodin a hloubkových, polostrukturovaných hloubkových rozhovorů s oběma pedagožkami jsme 
zjistili důležité skutečnosti efektivity vytváření schémat skupinové práce. Nejefektivnější pro motivaci a zájem žáků je sestavení skupin na základě intelektu a kognitivního stylu žáků. Žáci tak mohou plně rozvinout svou kreativitu, kritické myšlení a strategii řešení problému. Pro sestavení skupin je však podmínkou vytvoření specifických úloh, což je velmi náročné na př́ípravu pedagoga. Důležité je též přesné vymezení rolí ve skupinách a vzájemná spolupráce. Stejně tak je efektivně hodnocena i práce ve dvojicích. Nevýhodou je, že se skupiny se slabším prospěchem cítí segregovány při zadání jednodušších úloh a mnohdy potřebují pro řešení pomoc pedagoga či asistenta nebo opěrného materiálu, např. knihy či pracovního listu, kde mají nápovědu pro řešení v ateliéru s názvem Knihovna. Po zadání diagnostických prověrek měly výše zmíněné skupiny i pozitivní vliv na výsledky žáků. Skupiny založené dle typologie MBTI a metody Fie bezesporu rozvijí kreativitu žákủ, a především jejich kritické myšlení a mají tak pozitivní vliv na výsledky žáků. Paní učitelky z Pardubic a Hradce Králové se účastní šrroké škály školení a přednášek zaměřujících se na diferencovanou a individualizovanou výuku na 1 . stupni základní školy.

V základní venkovské škole ve Středočeském kraji a v základní škole v Čáslavi, byly sestaveny skupiny na základě zájmu žáků bez specifického zadání úloh. Tato skupinová práce je pouze zpestřením vyučovací hodiny a má vliv na vzájemnou interakci a socializaci žáků. Zde může nastat problém nevytíženosti všech žáků skupiny a $\mathrm{v}$ neschopnosti žáků se slabším prospěchem vyřešit zdárně zadaný úkol. Na základě našeho výzkumu bylo zjištěno, že dochází při implementaci skupinové práce do výuky ke zlepšení motivace žáků k učení a ke zlepšení sociální interakce mezi žáky při využití skupinové práce. Při sestavení homogenních skupin na základě intelektu, učebního stylu či typologie MBTI, dochází nejen ke zvýšení zájmu žáků o výuku, ale i o větší realizaci žáků při výuce a zlepšení jejich studijních výsledků.

\section{Závěr}

Provedli jsme závěrečnou, souhrnnou procentuální analýzu implementace pedagogických prostředků diferenciace a individualizace u zkoumaného vzorku základních škol a znázornili ji pomocí sloupcového grafu, (viz. graf 1). Prostřednictvím procent jsme vyjádřili míru implementace diferencované a individualizované výuky u jednotlivých škol. Základní škola v Hradci Králové využívala pedagogické prostředky diferencované a individualizované výuky v $99 \%$. Základní sídlištní škola v Pardubicích s velkou kapacitou žáků využívala pedagogické prostředky diferencované a individualizované výuky v 97 \%. Obě učitelky se účastní řady školení a seminářů zaměřených na diferenciaci, individualizaci a inkluzi. Na třetím místě s $39 \%$ využití diferencované a individualizované výuky se umístila základní škola v Čáslavi. Na čtvrtém místě pak s 37\% venkovská základní škola ve Středočeském kraji. Obě učitelky se zajímají o diferencovanou výuku a má $\mathrm{v}$ plánu se $\mathrm{v}$ této oblasti více vzdělávat. Na posledním, pátém místě se umístila menší základní škola $\mathrm{v}$ Pardubickém kraji. Učitelce $\mathrm{z}$ této školy byly poskytnuty semináře $\mathrm{z}$ naší strany. Škola bude procházet 
personálními změnami a bude se měnit též obsah ŠVP. Doporučili jsme zařadit do ŠVP diferenciaci a individualizaci učiva vzhledem $\mathrm{k}$ individuálním zvláštnostem žáků.

\section{Graf 1}

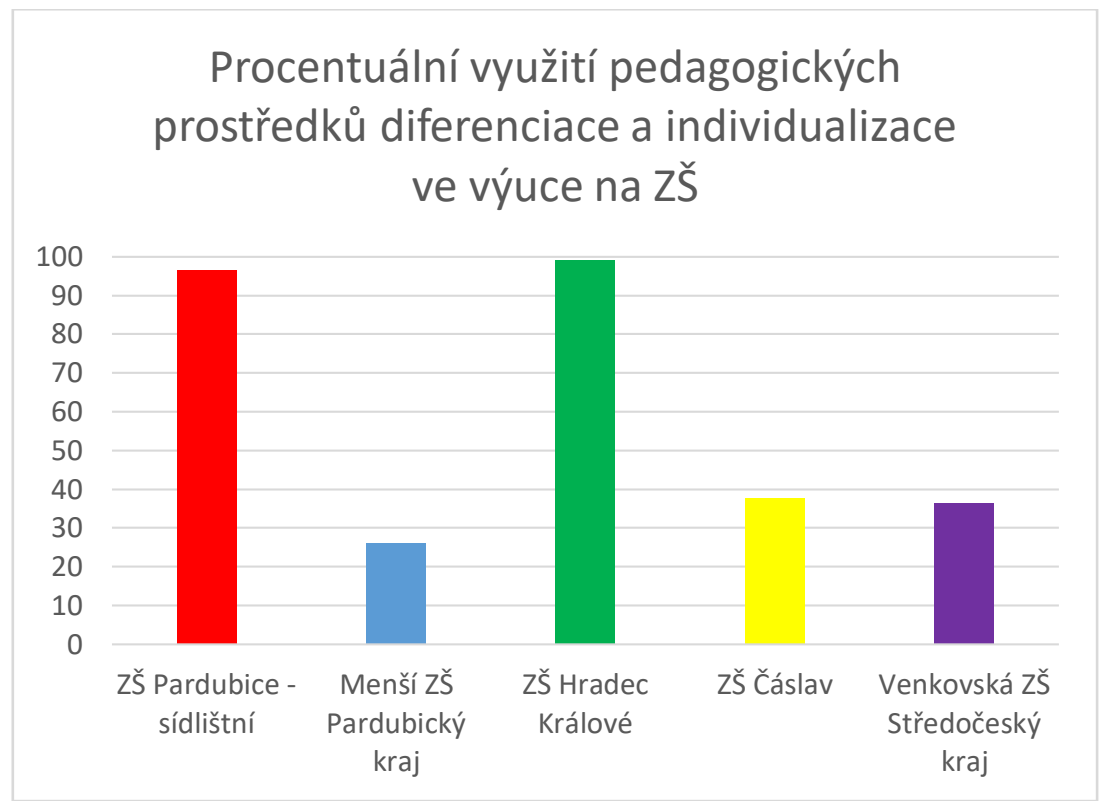

Na základě rozhovorů s učitelkami ze sídlištní hradecké a pardubické školy byly za nejdůležitější pedagogické prostředky diferencované a individualizované výuky považována především diferenciace rozsahu práce, diferenciace časového hlediska zadávání úkolu, diferenciace obtížnosti práce. Zajímavou spatřují též pečlivě připravenou práci ve skupinách založenou na základě intelektu, kognitivního stylu, metody Fie, a typologií MBTI, které budeme $\mathrm{v}$ dalších etapách podrobně zkoumat. Neméně, aby mohla být diferenciace úspěšná, je nezbytné dle všech pedagogů využití diferenciace jako podpůrné opatř̌ení. Nezbytná je též znalost odborné a pedagogické diagnostiky žáka. Důležitost pedagogického prostředku diferenciace a individualizace spatřují ve formativním hodnocení a sebehodnocení žáků, na základě, kterého získají velmi důležitou zpětnou vazbu. (Starý). 2016

Paní učitelky z menších škol dávají přednost individuální práci se žákem a skupinové práci sestavené na základě zájmu žáků. Jako rozšiřující učivo mají jen $\mathrm{z}$ učebnice ofocené materiály navíc. Problematika diferenciace a individualizace ve vyučovacím procesu je velice zajímá a chystají se zúčastnit série školení věnovaných diferencované a individualizované výuce. $\mathrm{V}$ našem výzkumu budeme $\mathrm{v}$ následujících dvou letech pokračovat.

Závěrem můžeme konstatovat, že diferenciace a individualizace není pro učitele neznámý pojem a $\mathrm{v}$ menší či větší míře ho ve školách $\mathrm{v}$ rámci vyučovacího procesu využívají. 
Věříme, že výsledky výzkumu mohou dát rovněž důležitou zprávu školskopolitické sféře a školní inspekci o tom, jak učitelé reálně pracují $\mathrm{s}$ individuálními zvláštnostmi žákủ při diferencované výuce a poskytnout pedagogům cenné informace a doporučení použitelné při vytváření dlouhodobější vize využívání diferencované a individualizované výuky. 


\section{Bibliographic references}

Amade-Escot C. (2005).Using the critical didactic incidents method to analyze the content taught. Journal of Teaching in Physical Education, 24, pp. 127-148.

Anderson, M. Kelly a Algozzine, Bob. (2010). Tips for Teaching: Differentiating Instruction to Include All Students. Taylor and Francis online 1(3), pp. 49-54, http://www.tandfonline.com/doi/abs/10.3200/PSFL.51.3.4954

Educational Research.Bartonova, M., \& Vitkova, M. (2017). Spolecne vzdelavani orientovane na posileni kompetenci ucitelu a zaku $\mathrm{v}$ inkluzivnim prostredi skoly. Brno: Masarykova univerzita

Bassey, M. (1999). Study research in Educational Settings. Buckhingham: University Press.

Boaler, J., William, D., \& Brown, M. (2000). Students' experiences of ability groupingdisaffection, polarisation and the construction of failure. British Educational Research Journal, 26(5), pp. 631-648.

Bray, B. \& McClaskey, K. 2013. A Step-by-step Guide to Personalize Learning. Students at the Center Hub. [Online] kveten 2013. http://studentsatthecenterhub.org/resource/a-step-by-step-guide-topersonalize-learning/

CSI. 2020-2021 Vyrocni zprava Ceske skolni inspekce za skolni rok20202021 Praha: Ceska skolni inspekce, https://www.csicr.cz/cz/Aktuality/Kvalita-a-efektivita-vzdelavani-avzdelavaci-s-(4)

Dewey, J., Demokracie a vychova. Praha 1932

DITTON, H. (2002). Unterrichtsqalitat - Konzeptionen, methodische Uberlegungen und Perspektiven. Unterrichtswissenschaft, 30(3), pp 197-212 Hallam, S. (2012). Streaming and setting in UK primary schools: evidence from the Millenium cohort study. Forum, 54(1), 57-63.

Hornby, G., \& Witte, Ch. (2014). Ability grouping in New Zeland high schools: Are practices evidence-based? Preventing School Failure, 58(2), 9095.

Janik, T., et al. (2016). Kvalita (ve) vzdelavani: obsahove zamereny pristup ke zkoumani a zlepsovani vyuky

Gamoran, A. (1992). Isability grouping equitable? Educational Leadership, 50(2), 11-17.

Greger, D. (2004). Koncept spravedlivosti a diferenciace zaku. In E. Walterova (Ed.), Uloha skoly v rozvoji vzdelanosti (s. 362-370). Brno: Paido.

Greger, D., \& Holubova, M. (2010). Postoje ucitelu k casnemu rozdelovani zaku a jejich zkusenosti $\mathrm{s}$ prechodem zaku do viceletych gymnazii. Pedagogicky casopis, 1(1), pp. 85-101.

HELUS, Z. (2004). Dite v osobnostnim pojeti. Obrat к diteti jako vyzva a ukol pro ucitele i rodice. Praha: Portal

Kasikova, H., Strakova, J. (2011). Diverzita a diferenciace v zakladnim vzdelavani. Praha: Karolinum. 
Kasikova, H., \& Valenta, J. (1994). Reformu dela ucitel aneb Diferenciace, individualizace a kooperace ve vyucovani. Praha: Sdruzeni pro tvorivou dramatiku: Cesky vybor ASSITEJ.

Komensky, J. A. (1948) Didaktika velka. 3. vyd. Brno: Komenium,

Kutnick, P., Sebba, J., Blatchford, P., Galton, M., \& Thorp, J. (2005). The effects of pupil grouping

Lechta, V. a kol. (2016). Inkluzivni pedagogika. Praha: Portal

Lucas, S. R. (2001). Effectively maintained inequality: Education transitions, track mobility, and social background effects. American Journal of Sociolog y, 106(6), pp. 1642-1690.

Mikova, S., \& Stang, J. (2015). Typologie osobnosti u deti: vyuziti ve vychove a vzdelavani (Vyd. 2). Portal.

Mittler, P. (2000). Working toward inlcusive education. London: David Fulton.

Mouralova, M. (2013). Postoje ceskych ucitelu k vnejsi diferenciaci zaku a mozne hodnotove koreny techto postoju. Orbis scholae, 7(3), pp. 11-26.

Narodni program rozvoje vzdelavani v Ceske republice: Bila kniha. (2001). Praha: Tauris.

OECD. (2002). Educational policy analysis. Paris: OECD.

Prast, E. J., Weijer-Bergsma, E. van de, Kroesbergen, E. H., \& Luit, J. E. H. van (2018). Differentiated instruction in primary mathematics: Effects of teacher professional development on student achievement. Learning and Instruction, 54, pp. 22-34.

Roubicek, F. \& Hospesova, A. (2010) Namety pro prirozenou diferenciaci v matematice na 1. Stupni zakladniho vzdelavani: Podnetna prostredi $\mathrm{v}$ geometrii.

Salamanca Statement and Framework for Action on Special Needs Education. (1994) UNESCO

Saleh, M., Lazonder, A. W., \& Jong, T. D. (2005). Effects of with in-class ability grouping on social interaction, achievement, and motivation. Instructional Science, 33(2), pp. 105-119.

Salchegger, S. (2016). Selective school system and academic self-concept: how explicit and implicit school-level tracking relate to big-fish-littlepondeffect across cultures. Journal of Educational Psycholog y, 108(3), pp. 405-423.

Strategie vzdelavaci politiky Ceske republiky do roku 2030+. (2020). from https://www.msmt.cz/vzdelavani/skolstvi-v-cr/strategie-2030.

Stary, K., Laufkova,V. a kol. (2016). Formativni hodnoceni ve vyuce. Praha: Portal.

Svaricek, R., Sedova, K. \& kol. (2014). Kvalitativni vyzkum v pedagogickych vedach. Praha: Portal.

Tieso, C. L. (2003). Ability grouping is not just tracking anymore. Roeper Review, 26(1), pp. 29-36.

Tomlinson, C. A. (2017). How to differentiate instruction in academically diverse classrooms (3rd ed.). Alexandria, VA: Association for Supervision and Curriculum Development.

Tucker, G. C. (2014). Differentiated Instruction: What You Need to Know. Understood - for learning and attention issues. [Online] Understood, 19. 8 
2014, https://www.understood.org/en/learning-attention-issues/treatmentsapproaches/educational-strategies/differentiated-instruction-what-you-needto-know.

Valisova, A., \& Kasikova, H. et al. (2007). Pedagogika pro ucitele. Praha: Grada.

Weinert, F. E. (ed.). (1997) Psychologie des Unterrichts und der Schule. Gottingen: Hogrefe,

Whitburn, J. (2010). Effective Classroom Organisation in Primary Schools: Mathematics. Taylor and Francis http://www.tandfonline.com/doi/abs/10.1080/03054980125200

Mgr. Monika Semrádová, MBA

Faculty of Education

Charles University

Magdalény Rettigové 47/4

11000 Praha 1

Czech Republic

semradovamonika@email.cz 